\title{
Bacterial bioleaching of low grade nickel limonite and saprolite ores by mixotrophic bacteria
}

\author{
Siti Khodijah Chaerun ${ }^{1,2, a}$, Siti Aisyah Alting ${ }^{2}$, Mohammad Zaki Mubarok ${ }^{1}$, and Edy Sanwani ${ }^{1}$ \\ ${ }^{1}$ Department of Metallurgical Engineering, Faculty of Mining and Petroleum Engineering, Institut Teknologi Bandung, \\ Ganesha 10, Bandung 40132, Indonesia \\ ${ }^{2}$ Geomicrobiology-Biomining \& Biocorrosion Laboratory, Microbial Culture Collection Laboratory, Biosciences and \\ Biotechnology Research Center, Institut Teknologi Bandung, Ganesha 10, Bandung 40132, West Java, Indonesia
}

\begin{abstract}
Utilization of indigenous bacteria should be considered to establish a successful biohydrometallurgical process. In this study, mixrotrophic iron-oxidizing bacterial consortia consisting of Comamonas testosteroni, Alicyclobacillus ferrooxydans and Pantoea septic which were isolated from Indonesian mineral ores were examined to determine their abilities to recover nickel from limonite and saprolite ores in the bioleaching experiments using stirred tank reactors. The nickel bioleaching experiments inoculated with the bacterial consortia were carried out using coarse limonite ores and weathered saprolite ores with pulp density of $10 \%$ w/v. Abiotic controls were also carried out replacing the inocula by the sterile medium. The bioleaching processes were monitored by measuring $\mathrm{Ni}$ and $\mathrm{Fe}$ contents and $\mathrm{pH}$ of the leaching solution as well as the total bacterial enzymatic activity measured as FDA hydrolytic activity. The effect of leaching on the mineralogy of laterite ores was investigated by the scanning electron microscope equipped with energy-dispersive spectroscopy (SEM-EDS) and X-ray powder diffraction (XRD). After 28 days of incubation, the FDA hydrolytic activity was observed in both bioleaching experiments containing limonite $(17.2 \mu \mathrm{g}$ fluorescein $/ \mathrm{mL})$ and saprolite ores $(16.9 \mu \mathrm{g}$ fluorescein $/ \mathrm{mL})$. The leached $\mathrm{Ni}$ and $\mathrm{Fe}$ in the bioleaching experiments containing limonite ores $(30 \% \mathrm{Ni}$ and $5.6 \% \mathrm{Fe})$ was greater than that in abiotic controls $(1 \% \mathrm{Ni}$ and $0.1 \% \mathrm{Fe}$ ) with the $\mathrm{pH}$ range of 2.5 to 3.5 . However, the bacterial consortia were less capable of bioleaching of $\mathrm{Ni}(2.5 \%)$ with the similar leached $\mathrm{Fe}(6 \%)$ from the saprolite ores. In abiotic controls, the medium $\mathrm{pH}$ remained relatively constant ( $\mathrm{pH}$ 6). It was concluded that these bacterial isolated as the consortium were capable of nickel bioleaching (precious metal) more effectively than iron (gangue metal), thus being applicable to the commercial processing of the difficult-to-process low-grade nickel laterite ores in Indonesia.
\end{abstract}

${ }^{\text {a }}$ Corresponding author: skchaerun@gmail.com 